of cerebral disease ; when they begin to decay, in advanced life, we are generally safe in predicting that, if neglected, other functions will sooner or later be impaired. When conscience is gone the constitation may soon follow.

Everybody has obserred that greediness, ill-temper, despondency, are oftentimes the first and only symptoms that disease is coming upon us. The moral nature is a delicate barometer that foretells long beforehand the coming storm in the system.

Moral decline as a symptom of cerebral disease, is, to say the least, as reliable as are many of the symptoms by which physicians are accustomed to make a diagnosis of various diseases of the organs of the body.

When a moral is associated with intellectual decline in advanced life, it is almost always safe to make a diagnosis of cerebral disease. Acting on this evidence alone, the speaker had diagnosticated cerebral disease in Mr. Greeley a year before his death, and by the same evidence he predicted that Sumner would probably die of disease of the brain of some kind, and would never again be very eloquent or morally enthusiastic.

Let nothing deprive us of our sleep. Early to bed and late to rise, makes the modern brain-toiler healthy and wise.

The problem of the future is work hard and at the same time take it easy. The more we have to do, the more we should sleep.

Let it never be forgotten that death in the aged is more frequently a slow process, than an event; a man may begin to die ten or fifteen years before he is buried.

4. These researches enforce the duty of especial kindness and charity for those in life's decline. The old are the wards of the young, and their moral defects, so often due to causes heyond their control, should at least receive as much consideration as diseases of a purely physical character.

There should be at least as much charity for a tired brain as for a broken leg.

Greeley, for example, was no more to be blamed for the moral declension of the last years of his life than for his insane ravings during his closing illness; his fault was behind all that, in overworking-in taking no vacation until he found a week in which to die.

These views, startling as they may just now appear, will in twentyfive years be regarded as commonplace. Their general acceptance will modify many medical, hygienic and political theories and customs, and will tend to diminish much of the unhappiness of the family and of the social circle.

\title{
The late Mr. Lutwidge.
}

Our readers will have seen with deep regret the announcement of the death of Mr. R. W. S. Lutwidge, who was so long connected with the Lunacy Board-first as secretary to the 
Commissioners, and afterwards as a Commissioner. While visiting Fisherton House Asylum, in company with $\mathrm{Mr}$. Wilkes, he was suddenly attacked by a patient, who struck him violently on the temple with a nail, which had evidently been concealed and prepared for the purpose of inflicting injury on some one. An attack of paralysis followed, which ended fatally at Salisbury. Mr. Lutwidge was 72 years of age, so that it was not probable that, in the natural course of events, he would have continued to perform his active duties as a Commissioner for many more years; but it is beyond measure sad that a long and useful life should have been brought to an end in so distressing a manner. Mr. Lutwidge will be generally regretted by those who were brought in contact with him in his official capacity, and who could not fail to appreciate the courteous and genial manners of a kind-hearted gentleman. It must needs be that accidents happen from time to time in asylums; indeed, the marvel is that they are not more numerous than they are, when we consider how many irresponsible beings, dangerous to themselves or to others, are collected in them. An event of this kind is well calculated to make us appreciate more justly than we perhaps commonly do the trials, the endurance, and the unwelcome work of those attendants upon the insane who are in constant intercourse with them, and from whom we demand a long-suffering and a gentleness that are more than human.

\section{PART II.-REVIEWS.}

\section{Asylum Reports for 1872.}

Among the crowd of reports with which we have been favoured this year, it is only necessary that we should notice a few, taken almost at random, and extract from these any passages which may be of special interest. Of all their official duties, the writing of the annual report must be to the majority of medical superintendents their most disagreeable one. They are supposed to be written for the information of Committees of Visitors, and, such being the case, need not contain more than the most meagre medical details. Yet it is advisable that each superintendent should utilise, for his own benefit and that of his brethren in the speciality, his asylum experiences, and place them on record. Now, it is more than questionable if it is a judicious plan to incorporate

vOL. XIX. 